http://journal.uinsgd.ac.id/index.php/biodjati

\title{
AMPHIBIANS DIVERSITY IN SULAP HILL AND WATERVANG DAM, LUBUKLINGGAU
}

\author{
Zico Fakhrur Rozi ${ }^{1 *}$, Dian Samitra ${ }^{2,3}$
}

Received : August 23, 2019

Accepted : May 03, 2020

DOI: 10.15575/biodjati.v5i1.5340

${ }^{1,2}$ Biology of Education, STKIP PGRI Lubuklinggau. Jl. Mayor Toha,

Kelurahan Air Kuti Lubuklinggau 31626

${ }^{3}$ Zoology Division, Generasi Biologi Indonesia, Gresik, East Java, Indonesia 61171

e-mail:

*1zico.fakhrurrozi@gmail.com

²dian.samitra@gmail.com

*Corresponding author
Abstract. Sulap Hill and Watervang Dam are located in the central of the city of Lubuklinggau, South Sumatra Province, which has a variety of organisms, including amphibians. This study aimed to determine the diversity of amphibian species in the area of Sulap Hill and Watervang Dam Lubuklinggau City. This research was conducted from June to August 2018. Data collection was an exploration method-combined visual encounter survey (VES). The samples obtained were identified at the Biology Education Laboratory, STKIP PGRI Lubuklinggau. Data analysis included species composition, diversity index, and Evenness index, and conservation status. The results of the study found 5 families, consist of 11 species: Duttaphyrnus melanotictus, Ingerophrynus divergens, Phrynoidis asper, Fejervarya cancrivora, Fejervarya limnocharis, Limnonectes kuhlii, Limnonectes macrodon, Limnonectes paramacrodon, Polypedates leucomystax, Hylarana erythraea, Ichthyophis sumatranus. The results of the data analysis showed that the amphibian diversity index in the Sulap hill (1.55) and Watervang dam (1.84) was categorized as low. The Evenness index in Sulap Hill (0.86) and Watervang Dam (0.88) was categorized as a high uniformity and stable community. Based on data from the International Union for Conservation of Nature and Natural Resources (IUCN) Red List, 8 species have the status of Least Concern, 1 species with Vulnerable status, 1 species with Near-threatened status and 1 species with data deficient status.

Keywords: amphibians, diversity, Lubuklinggau, Sulap Hill, Watervang Dam

\section{Citation}

Rozi, Z. F. \& Samitra, D. (2020). Amphibians Diversity in Sulap Hill and Watervang Dam, Lubuklinggau. Jurnal Biodjati, 5(1), 153-163.

\section{INTRODUCTION}

Lubuklinggau City is a city located in South Sumatra Province, lie on 129 meters above the sea-level (Badan Pusat Statistik, 2017). Lubuklinggau City has varied ecosystems such as hills, rivers and rice fields. Sulap Hill and the Watervang Dam are parts of Lubuklinggau city which have biodiversity potential.
Sulap Hill is a conservation area that presents a variety of flora and fauna. The Sulap Hill area is representative of the natural ecosystems of tropical rain forests with forest communities that have many species and are included in the lowland forest ecosystems (Taman Nasional Kerinci Seblat, 2013). According to Sunarya (2016), Sulap Hill is one of the natural tourism objects in the Kerinci Seblat National Park area under the Nation- 


\section{JURNAL BIDDJATI}

http://journal.uinsgd.ac.id/index.php/biodjati

al Park Management Section (SPTN) Region $\mathrm{V}$ of South Sumatra Province and is included in the natural tourism utilization zone. Sulap Hill, which is located in central Lubuklinggau, besides being used as a tourist destination, is also used by people in other fields including education and economics. The Watervang Dam is an educational tourism site, which was built by the Dutch government in 1941 to irrigate rice fields (Fauzi, 2018). The Watervang Dam has a paddy and river ecosystem. Both Sulap Hill and Watervang Dam have various types of organisms, one of which is the amphibians.

Amphibians are animals that live in moist areas and even some species cannot be separated from water throughout their lives (Kamsi, 2003). Amphibians are one of the constituent components of the ecosystem that have a very important role in the continuity of ecological processes, especially the food chain. As ecologically, amphibians function as the main consumers of prey such as insects or other invertebrates (Kusrini, 2013) and can be used as bio-indicators of environmental conditions (Izza \& Kurniawan, 2014).

Amphibians are one of the fauna that are vulnerable to the threat of extinction (Qurniawan et al., 2010). The high intensity of the tourist's visit poses a serious threat to degradation of the habitat and presence of amphibians in Sulap Hill and Watervang Dam. For conservation efforts, it is very important that amphibian diversity data are found in Sulap Hill and Watervang Dam. Knowledge of amphibian diversity is an important element in determining conservation policies and sustainable environmental management systems (Eprilurahman et al., 2011). Apart from that, the presence of amphibians has an important role in the balance of the ecosystem. Several studies have been conducted on amphibian diversity in tourist areas such as in Braja Harjo- sari Village, East Lampung Regency (Arista et al., 2017), Gunung Permisan Nature Tourism Park, South Bangka, Bangka Belitung Islands Province (Irwanto et al., 2019), Bajuin Waterfall Tourism Area Tanah Laut Regency (Huda, 2018). Amphibian research in Lubuklinggau is incomplete, most recently carried out at Bukit Sulap in 2008 (Kurniati, 2008). Even though, amphibian diversity studies would be useful for management conservation and to design regional protected areas for this group (Cahyadi \& Arifin, 2019; Jongsma et al., 2014; Wang et al., 2019). This study aimed to determine the diversity of amphibian species in the area of Sulap Hill and Watervang Dam Lubuklinggau City.

\section{MATERIALS AND METHODS}

\section{Research Sites}

This research was conducted from June to August 2018, in Sulap Hill and Watervang Dam, Lubuklinggau City, South Sumatra. The maps of the research location are presented (Figure 1).

\section{Sampling Method and Laboratory Activi- ties}

The method used in data collection was an exploration method/exploring combined visual encounter survey (VES) (Riyanto \& Mumpuni, 2013). The use of the VES method because each species has the same opportunity to be observed, the observed species have the same habitat, all individuals are counted only once in observation, the results of the study are observations outcome that conducted by more than one person. The researcher determined the location of observation and then performed a random search (wide patrolling). This method was generally used as it can reach a large area in a limited time. Searches were focused on places where amphibians are usually found. 


\section{JURNAL BIDDJATI}

http://journal.uinsgd.ac.id/index.php/biodjati



Figure 1. Research Location Map

Sampling/observation was carried out at 07.00-10.00 p.m West Indonesian Time (Eprilurahman et al., 2009), each location was repeated three times (Yani et al., 2015). Each species captured was stored in a plastic bag and given leaves, and then the identification was carried out at the Biology Education Laboratory of STKIP PGRI Lubuklinggau. The captured amphibians were identified refers to Kusrini (2013), Kamsi et al. (2017) and the International Union for Conservation of Nature and Natural Resources (IUCN) (2018) to see the conservation status of these species. After the identification process, the Amphibians were released back into their habitat (Samitra \& Rozi, 2020). The data collected including the number of species and time found. Data analysis consisted of Species Composition, Shannon-Wiener diversity, Evenness Index and Similarity Index (Krebs, 1978; Kusrini, 2009) using the following formulas:
Species Composition

$$
K J=\frac{n i}{N} \times 100 \%
$$

$\mathrm{Kj}=$ Composition $(\%) ; \mathrm{Ni}=$ Number of species-i individuals; $\mathrm{N}=$ number of individual species

Diversity Index

$$
H^{\prime}=-\sum \frac{n 1}{N} x \frac{n 1}{N}
$$

$\mathrm{H}^{\prime}=$ diversity index; $\mathrm{n} 1=$ number of type $\mathrm{i}$ individuals; $\mathrm{N}=$ number of individuals of all types. Criteria for Diversity Index $\left(\mathrm{H}^{\prime}\right)$ as follows: $\mathrm{H}^{\prime} \leq 2.0=$ low; $2.0<\mathrm{H}^{\prime}$ $\leq 3.0=$ medium; $\mathrm{H}^{\prime} \geq 3.0=$ high

Evenness Index

$$
E=\frac{H^{\prime}}{\ln S}
$$

$\mathrm{E}=$ Evennesss index $; \mathrm{H}^{\prime}=$ diversity index $; \mathrm{S}=$ number of types found. Criteria Evenness index $\mathrm{E}<0.5=$ Uniformity of Small Populations, Depressed Communities; $0.50>\mathrm{E} \leq 0.75=$ Uniformity of Medium Population, Ustable Community; $0.75<\mathrm{E} \leq 1=$ High Population Uniformity, Stable Community. 


\section{JURNAL BIDDJATI}

http://journal.uinsgd.ac.id/index.php/biodjati

Similarity Index

$$
\mathrm{IS}=\frac{2 C}{A+B}
$$

IS: Similarity index; $\mathrm{C}=$ the same number of species in both communities; $\mathrm{A}=$ number of species found only at location $1 ; \mathrm{B}=$ Number of species found only at location 2 .

\section{RESULTS AND DISCUSSION}

\section{Amphibia Composition}

There are as many as 11 species belonging to 2 orders and 5 families found in Sulap Hill and Watervang. The number of amphibians found in Sulap Hill was 6 species grouped into one order (Anura), in the Watervang Dam as many as 8 species belonging to 2 orders
(Anura and Gymnophiona) was found (Table 1). The different species found in Sulap Hil and Watervang Dam was due to the difference in habitat as the presence of amphibians influenced by their habitat type. The Watervang Dam has a macrohabitat suitable for amphibians, i.e., rivers, ponds, rice fields and trees (Putra et al., 2012). In addition to variations in species richness, the abundance, structure of assemblages and species composition differ from each region offered by the heterogeneity inherent in the region. These conditions are exploited differently by species or groups of species, even by threatened species (Meza-parral \& Pineda, 2015).

Table 1. Amphibians in Sulap Hill and Watervang Dam

\begin{tabular}{|c|c|c|c|c|}
\hline \multirow{2}{*}{ Order } & \multirow{2}{*}{ Family } & \multirow{2}{*}{ Species } & \multicolumn{2}{|c|}{ Location } \\
\hline & & & Sulap Hill & Watervang Dam \\
\hline \multirow{10}{*}{ Anura } & \multirow{3}{*}{ Bufonidae } & Duttaphyrnus melanotictus & + & + \\
\hline & & Ingerophrynu sdivergens & - & + \\
\hline & & Phrynoidis asper & - & + \\
\hline & \multirow{5}{*}{ Digroclossidae } & Fejervarya cancrivora & + & + \\
\hline & & Fejervarya limnocharis & + & + \\
\hline & & Limnonectes kuhlii & + & - \\
\hline & & Limnonectes macrodon & + & - \\
\hline & & Limnonectes paramacrodon & - & + \\
\hline & Rhacophoridae & Polypedates leucomystax & + & - \\
\hline & Ranidae & Hylarana erythraea & - & + \\
\hline Gymnophiona & Icththyophiidae & Ichthyophis sp. & - & + \\
\hline
\end{tabular}

where: + : found; - : not found

All types of Bufonidae families occupy forests or areas bordering forests. Genus Dutaphyrnus, Ingerophrynus and Phyrnoidis were the 3 genera of Bufonidae found during the study. This finding is considered very small because there are 8 genera in Sumatra (Kamsi et al., 2017). Dutaphyrnus melanoticus is a type of family of Bufonidae that can be found in the human environment. This is proven by the fact that it was found in the Rozi \& Samitra
Watervang Dam where many houses found around the dam. D. melanotictus in Sulap Hill has been recorded in the study by Kurniati (2008). The presence of D. melanotictus in Sulap Hill considered unusual because Sulap Hill is one of the areas of the Kerinci Seblat National Park. The Ingerophrynus genus found during the study was I. divergence, in the Watervang Dam. This genus can be found in primary forests and secondary forests and 


\section{JURNAL BIDDJATI}

http://journal.uinsgd.ac.id/index.php/biodjati

settlements bordering forests. The Phyrnoidis genus found was Phyrnoidis aspera, in the Watervang Dam. The Phyrnoidis genus can generally be found on the banks of rivers.

Fejervarya and Limnonectes is a genus of the family Digroclossidae which was discovered during the study. Digroclossidae has the characteristics of large leg muscles (Wanda et al., 2012). In Sumatra, there are three genera from this family (Kamsi et al., 2017). The genus of Occidozyga was unable to be found. Fejervarya genus was found in 2 species, Fejervarya cancrivora and Fejervarya limnocharis. Both of these species were found in two research locations. F. cancrivora and F. limnocharis are species found in Sumatra (Kamsi et al., 2017). The Fejervarya genus can generally be found in rice fields or open spaces. Genus Limnonectes found 3 species namely Limnonectes kuhlii, Limnonectes paramacrodon and Limnonectes macrodon. This finding is very small because there are 9 genera in Sumatra (Kamsi et al., 2017). Limnonectes in Sulap Hill found was L. kuhlii and L. macrodon, while L. paramacrodon was found in the Watervang Dam.

There was only one genus of Polypedates found from the family of Rhacophoridae during this study. This finding was considered very small as 8 genera found in Sumatra previously (Kamsi et al., 2017). Besides, there was only one species obtained from this genus namely Polypedates leucomystax that was only found in Sulap Hills, while there were 5 species found in Sumatra previously. This species can be found in areas that have plants such as forests and even close to human settlements because this type needs a light to prey on insects.

There were 3 genera from Ranidae's family previously found in Sumatera. However, in this study, only one genus of Hylarana was found while the genus of Huia and Odor- ana were not. Hylarana erythraea was only found in rice fields and ponds around Watervang Dam. This is the habitat of $H$. erythraea which can be found in puddles, ponds, rice fields and quiet rivers.

The family of Icththyophiidae (Order Gymnophiona) found was Ichthyophis sumatranus. There were 3 types of Icththyophiidae family found in Sumatra (Teynié et al., 2010). The species was found in the Watervang Dam outlet area which has a sandy and rocky bottom. The Icththyophiidae family can be found in sandy, rocky rivers and slow river flows. All species from the order of Gymnophiona are difficult to find because of their living habits in burrows around the river and only come out during heavy rains (Wanda et al., 2012). I. sumatranus was found in the Watervang Dam after heavy rains.

The most commonly found species in the Sulap Hill was P. leucomystax (28\%) because this place is more suitable as the habitat of $P$. leucomystax which usually lives in trees or plants around the forest (Kamsi et al., 2017; Saputra et al., 2016). However, the most common species found in Watervang Dam was F. cancrivora $(29 \%)$ because the Watervang Dam area is a man-made environment and found rice fields so that it is an ideal habitat for F. cancrivora (Kamsi et al., 2017). D. melanoticus was more commonly found in Watervang Dam (20\%) than in Sulap Hill (1\%), this is due to the tendencies of this species to live close to community settlements and can to adapt to activities around them (Kamsi et al., 2017; Kusrini, 2013; Saputra et al., 2016). Overall the most common species found were $F$. cancrivora $(21 \%)$ and $F$. limnocharis (21\%), while the least commonly found was Ichthyophis sumatranus (1\%).

Anura data in Sulap Hill has decreased compared to the results of previous study that found 12 species belonging to 5 fami- 


\section{JURNAL BIDDJATI}

http://journal.uinsgd.ac.id/index.php/biodjati

lies (Kurniati, 2008). The species that were not covered (58.33\%) including Phrynoidis aspera, Ingerophyrnus claviger, Microhyla heymonsi, Limnonectes blythii, Limnonectes crybetus, Chalcorana chalconata, Amnirana nicobariensis. This decrease in species is due to overexploitation, forest loss or land conversion (Kusrini, 2007). This was proved by the results of interviews with Sulap Hill officers who stated that the community has been caught the Anura several times, moreover, some part of the area has changed to be a tourist attraction and community plantation. Overexploitation happened as the community uses the amphibian species as bait for fishing. Besides the availability of food and natural enemies (predators and diseases) can change the number of Anura species somewhere (Duellman \& Trueb, 1994). Limnonectes macrodon is a species not found in previous studies.

Based on the conservation status of the International Union for Conservation of $\mathrm{Na}$ ture and Natural Resources (IUCN) Red list (2018), there were 8 species (73\%) amphibians in Sulap Hill and Watervang Dam that categorized as Least Concern. The number of species that categorized as Data Deficient, Near Threatened and Vulnerable was 1 species (9\%), namely Ichthyophis sumatranus, Limnonectes paramacrodon and Limnonectes macrodon respectively (Table 2 ). The species composition of $L$. paramacrodon $(2 \%), L$. macrodon (3\%) and Ichthyophis sumatranus $(1 \%)$ is low (Figure 3), so those species must receive special attention and get priority to be preserved because its existence in nature that rarely found.

\section{Ecological Index}

The diversity index of amphibian species in Sulap Hill and Watervang Dam is low (Table 3). This happens because these locations are a tourist attraction with a high intensity of visits so that it can indirectly disrupt the presence of amphibian species. Changes in the status of Sulap Hill and Watervang Dam into tourist attractions indirectly cause changes in the ecology of the region and impact to the population reduction of amphibians (Kusrini, 2007).

Table 2. List of Amphibia Conservation Status in Sulap Hill and Watervang Dam

\begin{tabular}{ll}
\hline \multicolumn{1}{c}{ Species } & Conservation Status \\
\hline Duttaphyrnus melanotictus & Least concern \\
Ingerophrynus divergens & Least concern \\
Phrynoidis asper & Least concern \\
Fejervarya cancrivora & Least concern \\
Fejervarya limnocharis & Least concern \\
Limnonectes kuhlii & Least concern \\
Limnonectes macrodon & Vulnerable \\
Limnonectes paramacrodon & Near threatened \\
Polypedates leucomystax & Least concern \\
Hylarana erythraea & Least concern \\
Ichthyophis sumatranus & Data Deficient \\
\hline
\end{tabular}




\section{JURNAL BIDDJATI}

http://journal.uinsgd.ac.id/index.php/biodjati

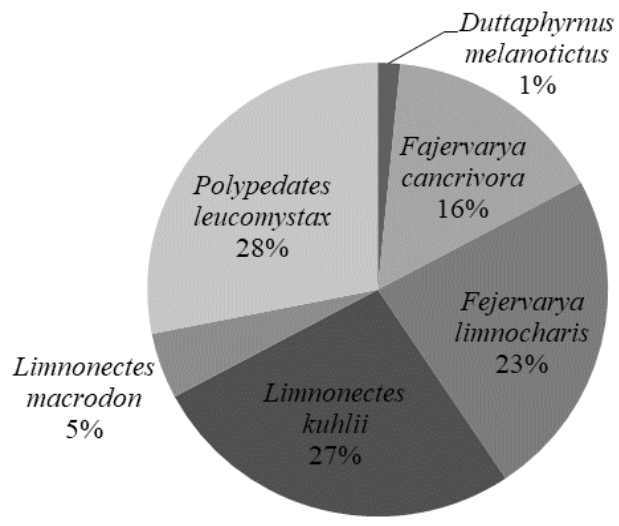

Figure 2. Amphibia composition in Sulap Hill

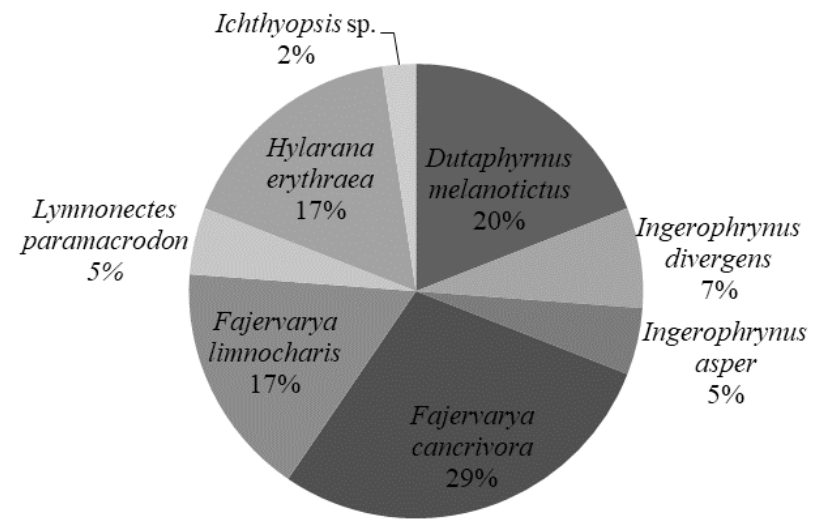

Figure 3. Amphibia composition in Watervang Dam



Figure 4. Overall Amphibia Composition

The Evenness index in Sulap Hill and Watervang Dam showed high population uniformity and stable communities (Table 4). This indicates that there is neither dominating species nor depressed species (Yudha et al., 2015). This is evident in the value of species composition (Figure $2 \& 3$ ) above $40 \%$.

The similarity index in Sulap Hill and Watervang Dam is 0.3 meaning that there is as much as $30 \%$ of species in both study locations that are the same (Table 5). Those species were $D$. melanotictus, F. limnocharis Jurnal Biodjati 5(1):153-163, May 2020 and $F$. cancrivora. Based on the results of measurements in the field, it was found that the temperatures in Sulap Hill and Watervang Dam ranged from $26.43-31.2^{\circ} \mathrm{C}$, while the air humidity ranged from $60.30-83.66 \%$ (Table 6). Temperature and humidity at the study site were still within the limits for populations of herpetofauna groups such as amphibians which are $20-40^{\circ} \mathrm{C}$ and $40-100 \%$ respectively (Khartik et al., 2018; Septiadi et al., 2018). In addition, the type of vegetation and air quality also affect amphibian life. The amphibians 


\section{JURNAL BIDDJATI}

http://journal.uinsgd.ac.id/index.php/biodjati

also need moisture to protect their skin (Izza \& Kurniawan, 2014). The air humidity in Sulap Hill is higher when compared to the Watervang Dam (Table 6) due to the vegetation type of lush and shaded by trees. From our study, 7 species were not found again in Sulap
Hill compared to previous studies by Kurniati (2008). Even though the temperature and humidity are still ideal for amphibian life. This happens because of human activity that causes a decrease in amphibians (Hayes et al., 2010).

Table 3. Diversity Index in Sulap Hill \& Watervang Dam

\begin{tabular}{lcc}
\hline \multicolumn{1}{c}{ Location } & Diversity Index & Category \\
\hline Sulap Hill & 1.55 & Low \\
Watervang Dam & 1.84 & Low \\
\hline
\end{tabular}

Table 4. Evenness index in Sulap Hill \& Watervang Dam

\begin{tabular}{lcc}
\hline \multicolumn{1}{c}{ Location } & Evenness Index & Category \\
\hline Sulap Hill & 0.86 & High Population Uniformity, Stable Community \\
Watervang Dam & 0.88 & High Population Uniformity, Stable Community \\
\hline
\end{tabular}

Table 5. Similarity Index

\begin{tabular}{lcc}
\hline \multicolumn{1}{c}{ Location } & Sulap Hill & Watervang Dam \\
\hline Sulap Hill & & \\
Watervang Dam & 0.3 & \\
\hline
\end{tabular}

Table 6. Abiotic Factor in Sulap Hill and Watervang Dam

\begin{tabular}{lcc}
\hline \multicolumn{1}{c}{ Parameter } & Sulap Hill & Watervang Dam \\
\hline Air Temperature $\left({ }^{\circ} \mathrm{C}\right)$ & 26.43 & 31.2 \\
Air Humdity $(\%)$ & 83.66 & 60.30 \\
\hline
\end{tabular}

Taken together, from this study results, it can be concluded that there were 11 species belonging to 5 families identified in the Sulap Hilland Watervang Dam. Sulap Hill and Water Dam have low diversity and a stable community. One species each was categorized as Near Threatened and Vulnerable. Until 2018, only Leptophyrne cruuntata is included in the list of protected animals (Pemerintah Indonesia, 2018). Though many statuses of amphibian species are included in the list Redlist of International Union for Conservation of Nature and Natural resources (IUCN) as of threatened and Near Vulnerable, it is necessary to revise the list of protected animals. InRozi \& Samitra troducing amphibians to the community must be done as an effort from the conservation department. The effort that has been made by the researcher is to build a community called the Simpul Herpetofauna Lubuklinggau.

Sulap Hill and the Watervang Dam have the same problems that are human activities. The impact that might occur as a result of this activity is the reduction of several types of amphibians and can reach extinctions in which these losses cannot be replaced with the material. In addition, the ecological function of Sulap Hill and the Watervang Dam as a store of genetic resources is also not working properly (Subeno, 2018). 


\section{JURNAL BIDDJATI}

http://journal.uinsgd.ac.id/index.php/biodjati

\section{ACKNOWLEDGEMENTS}

This research was funded by STKIP PGRI Lubuklinggau. We would like to thank LP4MK STKIP PGRI Lubuklinggau for facilitating so that this research can be carried out.

\section{REFERENCES}

Arista, A., Winarno, G. D. \& Hilmanto, R. (2017). Keanekaragaman Jenis Amfibi untuk Mendukung Kegiatan Ekowisata di Desa Braja Harjosari Kabupaten Lampung Timur. Biosfera, 34(3), 103 109.

Badan Pusat Statistik. (2017). Kota Lubuklinggau dalam Angka. Palembang: CV. Musi Copirindo.

Cahyadi, G. \& Arifin, U. (2019). Potential and Challenges on Amphibians and Reptiles Research in West Java. Jurnal Biodjati, 4(2), 149-162.

Duellman, W. E. \& Tureb, L. (1994). Biology of Amphibia. Baltimore \& London: The Johns Hopkins University Press.

Eprilurahman, R. \& Kusuma, K. I. (2011). Amfibi dan Reptil di Lereng Selatan Gunung Api Merapi Sebelum Erupsi 2010. A Scientific Periodical, 10(1), $1-8$.

Eprilurahman, R., Hilmy, M. F. \& Qurniawan, T. F. (2009). Studi Keanekaragaman Reptil dan Amfibi di Kawasan Ekowisata Linggo Asri, Pekalongan, Provinsi Jawa Tengah. Berkala Penelitian Haya$t i, 15(1), 93-97$.

Fauzi, T. R. (2018). Dam Watervang: Influence and the Development to the Present. Jurnal Arkeologi Siddhayatra, 23(1), 66-79.

Hayes, T. B., Falso, P., Gallipeau, S. \& Stice, M. (2010). The Cause of Global Amphibian Declines: a Developmental En- docrinologist's Perspective. The Journal of Experimental Biology, 213(6), 921-933.

Huda, N. (2018). Inventarisasi Keanekaragaman Amfibi di Kawasan Wisata Air Terjun Bajuin Kabupaten Tanah Laut. Jurnal Pendidikan Hayati, 4(2), 85-92.

Irwanto, R., Lingga, R., Pratama, R. \& Ifafah, S. A. (2019). Identifikasi Jenis-jenis Herpetofauna di Taman Wisata Alam Gunung Permisan, Bangka Selatan, Provinsi Kepulauan Bangka Belitung. PENDIPA Journal of Science Education, 3(2), 106-113.

IUCN. (2018). The IUCN Red List of Threatened Species. Version 2018-2. Retrieved from https://www.iucnredlist.org.

Izza, Q. \& Kurniawan, N. (2014). Eksplorasi Jenis-jenis Amfibi di Kawasan OWA Cangar dan Air Terjun Watu Ondo, Gunung Wilerang, TAHURA R.Soerjo. Jurnal Biotropika, 2(2), 103 -108.

Jongsma, G. F. M., Hedley, R. W., Durães, R. \& Karubian, J. (2014). Amphibian Diversity and Species Composition in Relation to Habitat Type and Alteration in the Mache-Chindul Reserve, Northwest Ecuador. Herpetologica, 70(1), 34-46.

Kamsi, M. (2003). Panduan Lapangan Amfibi Kawasan Ekosistem Leuser. Bogor: The Gibbon Foundation dan PILI-NGO Movement.

Kamsi, M., Handayani, S., Siregar, A. J. \& Fredriksson, G. (2017). Buku Panduan Lapangan Amfibi Reptil Kawasan Hutan Batang Toru. Medan: Herpetologer Mania Publishing

Karthik P, Kalaimani, A. \& Nagarajan, R. (2018). An Inventory on Herpetofauna with Emphasis on Conservation from Gingee Hills, Eastern-Ghats, Southern India. Asian J Conserv Biol, 7(1), 2-16. Krebs, C. J. (1978). Ecological Methodology. 


\section{JURNAL BIDDJATI}

http://journal.uinsgd.ac.id/index.php/biodjati

New York: Harper and Row Publisher.

Kurniati, H. (2008). Biodiversity and Natural History of Amphibians and Reptiles in Kerinci Seblat National Park, Sumatra, Indonesia. Final Report. Bogor: LIPI.

Kusrini, M. D. (2007). Konservasi Amfibi di Indonesia: Masalah Global danTantangan (Conservation of Amphibian in Indonesia: Global Problems and Challenges). Media Konservasi, 7(2), 89-95.

Kusrini, M. D. (2009). Pedoman Penelitian dan Survei Amphibia di Lapangan. Bogor: Departemen Konservasi Sumber daya Hutan dan Ekowisata Fakultas Kehutanan IPB.

Kusrini, M. D. (2013). Panduan Bergambar Identifikasi Amfibi Jawa Barat. Bogor: Fakultas Kehutanan IPB dan Direktorat Konservasi Keanekaragaman Hayati.

Meza-parral, Y. \& Pineda, E. (2015). Amphibian Diversity and Threatened Species in a Severely TransformedNeotropical Region in Mexico. PLoS ONE, 10(3), $1-14$.

Pemerintah Indonesia. (2018). Peraturan Menteri Lingkungan Hidup dan Kehutanan Republik Indonesia Nomor 106 Tahun 2018 tentang Jenis Tumbuhan dan Satwa yang Dilindungi. Jakarta: Kementerian Lingkungan Hidup dan Kehutanan Republik Indonesia.

Putra, K., Rizaldi \& Tjong, D. H. (2012). Komunitas Anura (Amphibia) pada Tiga Tipe Habitat Perairan di Kawasan Hutan Harapan Jambi. Jurnal Biologi Universitas Andalas, 1(2) 156-165.

Qurniawan, T. F., Asti, H. A. \& Eprilurahman, R. (2010). Studi Awal Komunitas Ordo Anura di Kawasan Ekowisata Sawangan, Magelang, Jawa Tengah. Majalah Ilmiah Biologi BIOSFERA: A Scientific Journal, 27(3) 119-125.

Riyanto, A \& Mumpuni. (2013). Herpetofau- na di Taman Nasional Bali Barat. Prosiding Seminar Nasional Biologi-IPA. Surabaya 19 Januari 2013.

Samitra, D. \& Rozi, Z. F. (2020). Short Communication: The Herpetofauna around Human Settlements in Lubuklinggau City, South Sumatra, Indonesia: Composition and Diversity, 21(4), 1432-1437.

Saputra, R., Yanti, A. H. \& Setyawati, T. R. (2016). Inventarisasi Jenis-Jenis Amfibi (Ordo Anura) di Areal Lahan Basah Sekitar Danau Sebadang Kecamatan Sebawi Kapubaten Sambas. Protobiont, 5(3), 33-40.

Septiadi, L., Hanifa, B. F., Khatimah, A., Indawati, Y. \& Alwi, M. Z. (2018). Study of reptile and amphibian diversity at Ledok Amprong Poncokusumo, Malang East Java. Jurnal Biotropika, 6(2), 45-53.

Subeno. (2018). Distribusi dan keanekaragaman Herpetofauna di Hulu Sungai Gunung Sindoro, Jawa Tengah. Jurnal Ilmu Kehutanan, 12(1), 40-51.

Sunarya, A. (2016). Sulap Hill. Lubuklinggau: Balai Besar TNKS.

Taman Nasional Kerinci Seblat. (2013). Desain Tapak Pengelolaan Pariwisata Alam Zona Pemanfaatan Sulap Hill Taman Nasional Kerinci Seblat. Sumatera Selatan Kota Lubuklinggau: Balai Besar Taman Nasional Kerinci Seblat.

Teynié, A., David, P. \& Ohler, A. (2010). Note on a Collection of Amphibians and Reptiles from Western Sumatra (Indonesia), with the Description of a New Species of the Genus Bufo. Zootaxa, 2416(1), 1-43.

Wanda, I. F., Novarino, W. \& Tjong, D.H. (2012). Jenis-Jenis Anura (Amphibia) Di Hutan Harapan, Jambi. Jurnal Biologi Universitas Andalas, 1(2), 99-107.

Wang, J., Liu, Y. H., Martin, K., Luo, F. \& 


\section{JURNAL BIDDJATI}

http://journal.uinsgd.ac.id/index.php/biodjati

Meng, L. Z. (2019). Implications of Continuous Amphibian Diversity Monitoring in Daweishan National Nature Reserve in tropical SE Yunnan, China. Global Ecology and Conservation, 20, $1-11$.

Yani, A., Said, S. \& Erianto. (2015). Keanekaragaman Jenis Amfibi Ordo Anura Di Kawasan Hutan Lindung Gunung Semahung Kecamatan Sengah Temila Kabupaten Landak Kalimantan Barat. Jurnal Hutan Lestari, 3(1), 15-20.
Yudha, D. S., Yonathan \& Eprilurahman, R. (2015). Keanekaragaman dan Kemerataan Spesies Anggota Ordo Anura di Lereng Gunung Merapi Tahun 2012. Majalah Ilmiah Biologi BIOSFERA: A Scientific Journal, 32(1), 1-10. 